\title{
Efficacy of subcutaneous tocilizumab in patients with rheumatoid arthritis and systemic sclerosis overlap syndrome: a report of two cases and review of the literature
}

\author{
Hiroki Wakabayashi ${ }^{1 *}$ (D, Hitoshi Kino², Makoto Kondo ${ }^{3}$, Keiichi Yamanaka ${ }^{3}$, Masahiro Hasegawa ${ }^{1}$ and Akihiro Sudo ${ }^{1}$
}

\begin{abstract}
Background: The details of two rheumatoid arthritis (RA) patients with systemic sclerosis (SSC) who were administered tocilizumab, an anti-interleukin-6 receptor antibody, are reported, along with a review of the literature.

Case presentation: Two RA patients with SSC with inadequate responses to disease-modifying antirheumatic drugs (DMARDs) were given tocilizumab 162 mg every 2 weeks for 18 months. RA disease activity was evaluated by the 28joint disease activity score with erythrocyte sedimentation rate (DAS28-ESR) and the clinical disease activity index (CDAI). The skin condition of SSc was evaluated by pinching the skin according to the modified Rodnan total skin thickness score (mRSS). Softening of the skin and improvements of arthritis and the patient global assessment were observed during tocilizumab treatment, with reduction of not only RA disease activity, but also of the mRSS.

Conclusion: Tocilizumab may be effective in patients with RA and SSc overlap syndrome for which conventional treatment is inadequate. Further research is needed because this report included only two patients.
\end{abstract}

Keywords: Rheumatoid arthritis, Systemic sclerosis, Interleukin-6, Tocilizumab

\section{Background}

Systemic sclerosis (SSc) is a connective tissue disease that develops sclerotic changes characterized by obliterative and proliferative microvascular involvement, activation of the immune system and increase of extracellular matrix deposition in the skin and various internal organs [1]. SSc presents stiffness of extremities due to sclerosis and joint swelling in the skin and periarticular connective tissues. Visceral involvement during the course of the disease (pulmonary, cardiac, gastrointestinal, and renal complications) is factors related to mortality $[2,3]$.

Interleukin 6 (IL-6) is a pleiotropic proinflammatory multifunctional cytokine such as $\mathrm{T}$ cell activation, initiation of acute-phase reactants (e.g., C-reactive protein),

\footnotetext{
* Correspondence: whiroki@clin.medic.mie-u.ac.jp

'Department of Orthopaedic Surgery, Mie University Graduate School of Medicine, 2-174 Edobashi, Tsu, Mie 514-8507, Japan

Full list of author information is available at the end of the article
}

and stimulation of hematopoietic precursor cell growth, causing maturation of $\mathrm{B}$ cells into antibody-producing cells and cell differentiation. IL-6 overexpression and pathogenicity have been demonstrated in SSc as well as rheumatoid arthritis (RA) [4]. Tocilizumab (TCZ), an anti-IL-6 receptor antibody, blocks the functions of IL-6, and its efficacy for the treatment of RA, juvenile idiopathic arthritis, and Castleman's disease has been verified [5].

A mini-series of two RA patients with refractory SSc (cases 1 and 2), treated with TCZ (162 mg every 2 weeks), is reported.

\section{Case presentations}

Case 1: a 74-year-old Japanese woman at the time of starting tocilizumab treatment

The patient had joint pain and swelling in 2003. She was diagnosed with RA and treated with disease-modifying antirheumatic drugs (DMARDs). In 2015, the right wrist

(c) The Author(s). 2019 Open Access This article is distributed under the terms of the Creative Commons Attribution 4.0 International License (http://creativecommons.org/licenses/by/4.0/), which permits unrestricted use, distribution, and reproduction in any medium, provided you give appropriate credit to the original author(s) and the source, provide a link to the Creative Commons license, and indicate if changes were made. The Creative Commons Public Domain Dedication waiver (http://creativecommons.org/publicdomain/zero/1.0/) applies to the data made available in this article, unless otherwise stated. 
joint was swollen and tender, and the CRP level increased to $2.83 \mathrm{mg} / \mathrm{dl}$ (normal value $<0.3 \mathrm{mg} / \mathrm{dl}$ ). Although she received treatment for RA with methotrexate (MTX), salazosulfapyridine (SASP), and steroids, her arthritis was poorly controlled. In December 2015, because her arthritis worsened, she visited our hospital. Scleroderma from the fingers to the forearms was also observed at the first visit.

Anti-nuclear antibody (ANA) was 1280× (centromere), anti-cyclic citrullinated peptide antibody (ACPA) was 150 $\mathrm{U} / \mathrm{ml}$ (normal value $\leq 4.5 \mathrm{U} / \mathrm{ml}$ ), rheumatoid factor (RF) was $52 \mathrm{IU} / \mathrm{ml}$ (normal value $\leq 15 \mathrm{IU} / \mathrm{ml}$ ), and anti-centromere antibody was $17.8 \mathrm{IU} / \mathrm{ml}$ (normal value $\leq 7.0 \mathrm{U} / \mathrm{ml}$ ); all of them were elevated, but antibodies against topoisomerase I and U1-RNP were negative. The skin sclerosis developed from her fingers and expanded to her forearms, face, and feet. Chest computed tomography (CT) showed slight interstitial lung disease in the bilateral lower lung areas. The patient met the classification criteria for SSc established by the ACR/EULAR criteria in 2013 [6]. The patient was diagnosed with overlap syndrome involving RA and SSc. Larsen grade 3 was observed on both wrist and ankle X-rays, and grade 4 was observed on the left elbow X-ray. The 28-joint disease activity score with erythrocyte sedimentation rate (DAS28-ESR) and the clinical disease activity index (CDAI) were high, at 5.66 and 31.8 , respectively. The modified Rodnan total skin thickness score (mRSS) was 23.

Both the RA and SSc were judged to be active, and it was decided to treat the patient with TCZ, $162 \mathrm{mg}$ every 2 weeks. Administration of steroid (prednisolone $5 \mathrm{mg}$ / day) and DMARDs (MTX $6 \mathrm{mg} /$ week and SASP 1000 $\mathrm{mg} /$ day) was continued (Fig. 1a). During the 18-month period of TCZ therapy, TCZ was well tolerated, and the patient experienced general improvement in normal daily activities. At 18 months, the patient global assessment improved by 71 (75 to 4 ), the DAS28-ESR decreased from 5.66 to 1.10 , the CDAI decreased from 31.8 to 5.5 , and skin thickness evaluated with the mRSS improved from 23 to 3 (Fig. 1a). Reductions of both RA disease activity and of mRSS were seen.

There were no remarkable adverse events. Interstitial pneumonia did not change during the treatment period.

\section{Case 2: a 65-year-old Japanese woman at the time of starting tocilizumab treatment}

This patient with a history of RA diagnosed at 27 years of age underwent right wrist arthroplasty. After arthroplasty, she had been receiving sodium gold thiomalate $\left(\right.$ Shiosol $\left.^{\circ}\right)$ for 7 years, which relieved her joint symptoms. However, she abruptly stopped outpatient visits, and was lost to follow-up.

In 2010, she was affected by joint pain, swelling and scleroderma of the palms, and visited our hospital again.
The skin sclerosis developed from her fingers and expanded to her forearms, face, and feet. The findings of her right forearm skin biopsy were found to be consistent with SSc. She was diagnosed with overlap syndrome involving RA and SSc. She received treatment with cyclosporine, SASP, and steroids for RA and SSc treatment. Though an initial response was seen, the arthritis worsened. In 2016, both wrist joints were swollen and tender, and the CRP level increased to $1.05 \mathrm{mg} / \mathrm{dl}$ (normal value $<0.3 \mathrm{mg} / \mathrm{dl}$ ). Larsen grade 3 was observed on wrist X-rays. A CT study showed patchy infiltrates associated with ground-glass opacities in the bilateral lower lung areas. ANA was 320× (homogeneous), ACPA was $151 \mathrm{U} / \mathrm{ml}$ (normal value $\leq 4.5 \mathrm{U} / \mathrm{ml}$ ), RF was $229 \mathrm{IU} / \mathrm{ml}$ (normal value $\leq 15 \mathrm{IU} / \mathrm{ml}$ ), and anti-topoisomerase I antibody was $88.7 \mathrm{U} / \mathrm{ml}$ (normal value $\leq 7.0 \mathrm{U} / \mathrm{ml}$ ); all of them were increased, but antibodies against centromere and U1-RNP were negative. DAS28-ESR and CDAI were high, at 7.14 and 34.6, respectively. Skin sclerosis developed from her fingers to her forearms and face, and the mRSS was 15.

Both the RA and SSc were judged to be active, and it was decided to treat the patient with TCZ, $162 \mathrm{mg}$ every 2 weeks. Administration of steroid $(7 \mathrm{mg} /$ day) and a DMARD (cyclosporine $150 \mathrm{mg} /$ day) was continued (Fig. 1b). During the 18-month period of TCZ therapy, both RA disease activity and mRSS decreased. At 18 months, the patient global assessment improved by 32 (68 to 36), RA disease activity decreased (DAS28-ESR decreased from 7.14 to 3.70; CDAI decreased from 34.6 to 8.4), and skin thickness evaluated with the mRSS improved from 15 to 7 (Fig. 1b).

Interstitial pneumonia did not change during the treatment period. This patient developed cellulitis in the right foot plantar region at 6 weeks of treatment as an adverse reaction. TCZ was withdrawn for 4 weeks, but after the cellulitis resolved, she continued TCZ treatment.

\section{Discussion and conclusions}

Recent progress in medicine has dramatically improved the treatment and mortality of patients with rheumatic diseases such as RA [7]. However, radical therapy for SSc has not been developed and remains disappointing, with high mortality.

IL-6 is a multifunctional cytokine that regulates immune responses and induces acute phase responses. Despite the critical physiological activities of IL-6, excessive production of IL-6 is pathologically involved in various immune-mediated inflammatory diseases, including RA [8].

Extensive studies have demonstrated that IL-6 plays a pivotal role in the pathogenesis of SSc. According to a previous report by Khan et al., IL-6 is upregulated in dermal fibroblasts, endothelial cells, and perivascular inflammatory cells in the majority of early diffuse cutaneous SSc 


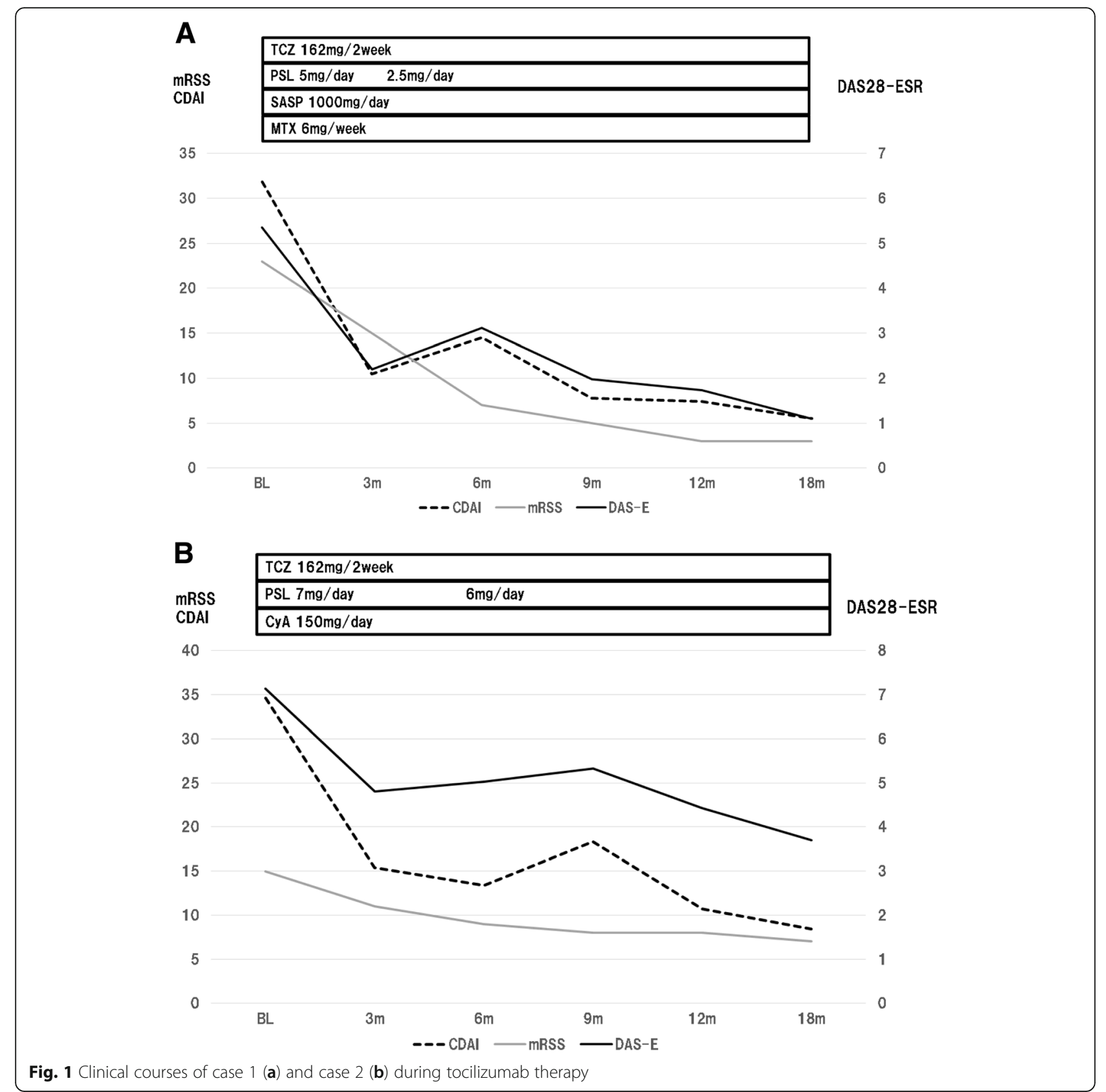

cases [9]. Furthermore, high serum IL-6 levels are associated with the severity of skin sclerosis, as well as reduced survival $[4,9]$.

TCZ administration proved beneficial for the skin sclerosis in the present cases, as reported previously (Table 1) [10-17]. In a recent phase 2 trial, TCZ was shown to have promising effects on skin in SSc [14].

Although there have been many cases in which TCZ improved sclerosis of the skin, in some patients, TCZ was stopped for inefficacy with respect to skin sclerosis and/or adverse events. Elhai et al. reported that, in two patients (13.3\%) [15], TCZ was stopped because of inefficacy after
3 months. The faSScinate study, a phase II trial, reported that treatment was discontinued because of inefficacy in one patient (2.3\%) [14]. Since the stage of the patient's skin thickening was late phase and involved only the fingers, it might be difficult to evaluate the improvement of skin thickening [16]. In the present study, the reason why skin improvement was small in case 2 may be the longer disease duration of SSc (Table 1).

The most common adverse events in the faSScinate study were infections, gastrointestinal disorders, skin or subcutaneous disorders, and musculoskeletal or connective tissue disorders. Treatment was withdrawn for 
Table 1 Previous reports of treatment with tocilizumab in systemic sclerosis patients with or without rheumatoid arthritis

\begin{tabular}{|c|c|c|c|c|c|c|c|c|c|}
\hline Author & Shima $Y$, & $\begin{array}{l}\text { Fernandes } \\
\text { das NM }\end{array}$ & Frech TM & Shima $Y$ & Khanna D & Elhai M & Saito E & Kono M & Presentcases \\
\hline Reference (Year) & $\begin{array}{l}\text { Ref10 } \\
(2010)\end{array}$ & Ref11 (2015) & Ref12 (2015) & $\begin{array}{l}\text { Ref13 } \\
\text { (2015) }\end{array}$ & $\begin{array}{l}\text { Ref14 } \\
\text { (2016) }\end{array}$ & Ref15 (2013) & $\begin{array}{l}\text { ref16 } \\
\text { (2014) }\end{array}$ & $\begin{array}{l}\text { ref17 } \\
(2017)\end{array}$ & 2018 \\
\hline Diagnosis & SSC & $\begin{array}{l}\text { SSC, (P3 } \\
\text { SSC/RA) }\end{array}$ & SSC & SSC & SSC & SSc/Arthritis & $\mathrm{SSc} / \mathrm{RA}$ & SSC/RA & SSC/RA \\
\hline Country (centers) & Japan & Portugal & USA & Japan & USA & EULAR & Japan & Japan & Japan \\
\hline $\begin{array}{l}\text { Number of patients } \\
\text { (n) }\end{array}$ & 2 & 3 & 2 & 1 & 43 & 15 & 1 & 2 & 2 \\
\hline $\begin{array}{l}\text { Age, years (SD } \\
\text { or range) }\end{array}$ & 42,57 & $55,42,54$ & 56,68 & 59 & $51 \pm 11.7$ & $56(45-61)$ & 57 & 25,32 & 74,65 \\
\hline $\begin{array}{l}\text { Duration of SSC, years } \\
\text { (SD or range) }\end{array}$ & 2,3 & $3,8,1$ & ns, 0.25 & 4 & $1.46 \pm 1.16$ & $5(4-9)$ & 2.5 & 2,3 & 1,6 \\
\hline Durationof RA, years & & & & & & & 2.5 & $0.25,3$ & 12,38 \\
\hline Female, n (\%) & $1(50 \%)$ & $3(100 \%)$ & $2(100 \%)$ & $\begin{array}{l}1 \\
(100 \%)\end{array}$ & $32(74 \%)$ & $13(86.7 \%)$ & $1(100 \%)$ & $1(50 \%)$ & $2(100 \%)$ \\
\hline Anti-nuclear antibody & $2(100 \%)$ & $3(100 \%)$ & $2(100 \%)$ & + & & & + & $2(100 \%)$ & $2(100 \%)$ \\
\hline $\begin{array}{l}\text { Anti-RNA polymerase } \\
\text { antibody }\end{array}$ & & & $\mathrm{P} 1+, \mathrm{P} 2-$ & + & $13(30 \%)$ & & & & \\
\hline $\begin{array}{l}\text { Anti-topoisomerase } \\
\text { antibody }\end{array}$ & P1-, P2+ & P1-, P2+, P3+ & & - & $18(42 \%)$ & 10 (76.9\%) & & $\begin{array}{l}\text { P1+, P2- } \\
\text { P2:U1-RNP+ }\end{array}$ & P1-, P2+ \\
\hline $\begin{array}{l}\text { Anti-centromere } \\
\text { antibody }\end{array}$ & & & & - & & $1(7.7 \%)$ & & & $\mathrm{P} 1+, \mathrm{P} 2-$ \\
\hline Anti-CCP antibody & & P1-, P2-, P3+ & & & & $3(37.5 \%)$ & + & $2(100 \%)$ & $2(100 \%)$ \\
\hline Rheumatoid factor & & P1-, P2-, P3+ & & & & $3(37.5 \%)$ & + & & $2(100 \%)$ \\
\hline $\begin{array}{l}\text { Previous biological } \\
\text { drugs }\end{array}$ & & P3: ADA, ETN & & & & $\begin{array}{l}\text { RTX:3, ABT:1, } \\
\text { TNF: } 2\end{array}$ & IFX & & \\
\hline $\begin{array}{l}\text { Immunosuppressive } \\
\text { drugs }\end{array}$ & P1: CyA & $\begin{array}{l}\text { P1: } \\
\text { CyA,AZA,HCQ } \\
\text { P2: CyA,AZA } \\
\text { P3: MTX,HCQ }\end{array}$ & & & $22(51 \%)$ & $\begin{array}{l}\text { MTX: } 8 \\
(57.1 \%)\end{array}$ & $\begin{array}{l}\text { MTX, } \\
\text { TAC, } \\
\text { SASP }\end{array}$ & $\begin{array}{l}\text { P1: } \\
\text { IVCY,TAC } \\
\text { P2: SASP }\end{array}$ & $\begin{array}{l}\text { P1: MTX, } \\
\text { SASP } \\
\text { P2: CyA }\end{array}$ \\
\hline $\begin{array}{l}\text { Concomitant systemic } \\
\text { corticosteroid use }\end{array}$ & $2(100 \%)$ & $3(100 \%)$ & & + & $21(49 \%)$ & $\begin{array}{l}11 \mathrm{pts} .(73.3 \%) \\
{[\leq 10 \mathrm{mg}]}\end{array}$ & & $2(100 \%)$ & $2(100 \%)$ \\
\hline Follow-up (months) & 6 & 6 & several, 26 & 16 & 12 & 5 (3 to 11.5 ) & 9 & 12 & 18 \\
\hline Tocilizumab dose & $\begin{array}{l}8 \mathrm{mg} / \mathrm{kg} / 4 \\
\text { w iv }\end{array}$ & $\begin{array}{l}8 \mathrm{mg} / \mathrm{kg} / 4 \\
\text { w iv }\end{array}$ & ns & $\begin{array}{l}8 \mathrm{mg} / \\
\mathrm{kg} / 4 \mathrm{~W} \\
\text { iv }\end{array}$ & $162 \mathrm{mg} / \mathrm{w}$ & $\begin{array}{l}8 \mathrm{mg} / \mathrm{kg} / \\
\text { month iv }\end{array}$ & $\begin{array}{l}600 \mathrm{mg} / \\
\text { month }\end{array}$ & $\begin{array}{l}\text { P1: iv, P2: } \\
\text { SC }\end{array}$ & $162 \mathrm{mg} / 2 \mathrm{w}$ \\
\hline mRSS baseline & 27,26 & $17,41,7$ & 22,27 & 35 & $26.4 \pm 7.2$ & $\begin{array}{l}15(4.5 \text { to } \\
24.0)\end{array}$ & & 25,14 & 23,15 \\
\hline mRSS last infusion & 13,20 & $11,25,5$ & 17,6 & 7 & $19.6 \pm 10.1$ & $\begin{array}{l}12(3.8 \\
\text { to } 16.3)\end{array}$ & $\begin{array}{l}\text { Not } \\
\text { improved }\end{array}$ & 8,5 & 3,7 \\
\hline DAS baseline & & P3: 3.82 & & & & $\begin{array}{l}5.2(3.9 \\
\text { to } 6.1)\end{array}$ & 5.39 & $2.92,6.92$ & $5.66,7.14$ \\
\hline DAS last infusion & & P3: 2.87 & & & & $\begin{array}{l}2.8(2.2 \\
\text { to } 3.4)\end{array}$ & 1.53 & $1.76,1.1$ & $1.10,3.70$ \\
\hline PGA baseline & & $70,70,60$ & & & & & & & 75,68 \\
\hline PGA last infusion & & $40,30,10$ & & & & & & & 4,36 \\
\hline $\begin{array}{l}\text { Discontinued for lack } \\
\text { of efficacy }\end{array}$ & & & & & $1(2.3 \%)$ & $2(13.3 \%)$ & & & \\
\hline $\begin{array}{l}\text { Discontinued for } \\
\text { adverse events }\end{array}$ & & & 1 (gastroenterology) & & $5(11.6 \%)$ & & & & \\
\hline
\end{tabular}

P1-3 patients 1-3, iv intravenous, sc subcutaneous, ns not shown

CyA cyclosporine, AZA azathioprine, HCQ hydroxychloroquine, MTX methotrexate, IVCY intravenous cyclophosphamide, TAC tacrolimus, ADA adalimumab, ETN etanercept, IFX infliximab, TNF tumor necrosis factor, RTX rituximab, $A B T$ abatacept, DAS disease activity score, $P G A$ patient global assessment 
adverse events in 11.6\% (5 patients) of patients after 12 months. Although case 2 in the present study had cellulitis of the right foot plantar region, she continued TCZ after the cellulitis resolved.

In the present study, two patients with overlapping RA and SSc who were successfully treated with TCZ for polyarthritis as well as skin sclerosis were reported. TCZ administration clearly resulted in improvement of joint disease activity and skin scores in these cases, as well as previously reported cases of RA and SSc overlap patients. TCZ treatment may be useful in patients with RA and SSc overlap syndrome for whom conventional treatment is inadequate. However, as a limitation, the current report included only two cases, and it is therefore difficult to draw any conclusions. Further research is needed.

\section{Abbreviations}

ACPA: Anti-cyclic citrullinated peptide antibody; ANA: Anti-nuclear antibody; CDAl: Clinical disease activity index; CRP : C-reactive protein; $C$ : Computed tomography; DAS: Disease activity score; DMARDs: Disease-modifying antirheumatic drugs; ESR: Erythrocyte sedimentation rate; IL-6: Interleukin-6; mRSS: modified Rodnan total skin score; MTX: Methotrexate; RA : Rheumatoid arthritis; RF: Rheumatoid factor; RNP: Ribonucleoprotein;

SASP: Salazosulfapyridine; SSC : Systemic sclerosis; TCZ : Tocilizumab

\section{Acknowledgements}

Not applicable.

\section{Funding}

No funding was obtained for this study.

\section{Availability of data and materials}

All data concerning the cases are presented in the manuscript.

\section{Authors' contributions}

HW was the corresponding author responsible for the writing of the article. $H W, H K$, and MK managed the patients. HW and KY participated in the care of the patients. $\mathrm{MH}$ and AS undertook the literature search. All of the authors read and approved the final manuscript.

\section{Ethics approval and consent to participate}

Ethics approval to publish a case report is not needed from our institute (Mie University Graduate School of Medicine).

\section{Consent for publication}

The authors obtained written consent from both patients for the publication of the data.

\section{Competing interests}

The authors declare that they have no competing interests.

\section{Publisher's Note}

Springer Nature remains neutral with regard to jurisdictional claims in published maps and institutional affiliations.

\section{Author details}

${ }^{1}$ Department of Orthopaedic Surgery, Mie University Graduate School of Medicine, 2-174 Edobashi, Tsu, Mie 514-8507, Japan. ${ }^{2}$ Kino Orthopedic Clinic, 4-1-7 Kikyogaoka, Nabari, Mie 518-0624, Japan. ${ }^{3}$ Department of Dermatology, Mie University Graduate School of Medicine, 2-174 Edobashi, Tsu, Mie 514-8507, Japan.
Received: 31 July 2018 Accepted: 25 March 2019

Published online: 24 April 2019

\section{References}

1. Barsotti S, Stagnaro C, Della Rossa A. Systemic sclerosis: a critical digest of the recent literature. Clin Exp Rheumatol. 2015;33(4 Suppl 91):S3-14.

2. Rubio-Rivas $M$, Corbella X, Pestaña-Fernández $M$, et al. First clinical symptom as a prognostic factor in systemic sclerosis: results of a retrospective nationwide cohort study. Clin Rheumatol. 2018;37(4):999-1009.

3. Mihai C, Antic M, Dobrota R, et al. Factors associated with disease progression in early-diagnosed pulmonary arterial hypertension associated with systemic sclerosis: longitudinal data from the DETECT cohort. Ann Rheum Dis. 2018;77(1):128-32.

4. Muangchan C, Pope JE. Interleukin 6 in systemic sclerosis and potential implications for targeted therapy. J Rheumatol. 2012:39:1120-4.

5. Schoels MM, van der Heijde D, Breedveld FC, et al. Blocking the effects of interleukin-6 in rheumatoid arthritis and other inflammatory rheumatic diseases: systematic literature review and meta-analysis informing a consensus statement. Ann Rheum Dis. 2013;72:583-9.

6. van den Hoogen F, Khanna D, Fransen J, et al. 2013 classification criteria for systemic sclerosis: an American college of rheumatology/European league against rheumatism collaborative initiative. Ann Rheum Dis. 2013;72:1747-55.

7. Zhang Y, Lu N, Peloquin C, et al. Improved survival in rheumatoid arthritis: a general population-based cohort study. Ann Rheum Dis. 2017;76:408-13.

8. Denton CP. Systemic sclerosis: from pathogenesis to targeted therapy. Clin Exp Rheumatol. 2015:33(4 Suppl 92):S3-7.

9. Khan K, Xu S, Nihtyanova S, et al. Clinical and pathological significance of interleukin 6 overexpression in systemic sclerosis. Ann Rheum Dis. 2012;71:1235-42.

10. Shima $Y$, Kuwahara $Y$, Murota $H$, et al. The skin of patients with systemic sclerosis softened during the treatment with anti-IL-6 receptor antibody tocilizumab. Rheumatology (Oxford). 2010;49:2408-12.

11. Fernandes das Neves M, Oliveira S, Amaral MC, Delgado Alves J. Treatment of systemic sclerosis with tocilizumab. Rheumatology (Oxford). 2015;54:371-2.

12. Frech TM, Hudson M. Protective role of interleukin- 6 in systemic sclerosis gastrointestinal tract involvement: case report and review of the literature Clin Exp Rheumatol. 2015;33(4 Suppl 91):S179-81.

13. Shima $Y$, Hosen $N$, Hirano $T$, et al. Expansion of range of joint motion following treatment of systemic sclerosis with tocilizumab. Mod Rheumatol. 2015:25:134-7.

14. Khanna D, Denton CP, Jahreis A, et al. Safety and efficacy of subcutaneous tocilizumab in adults with systemic sclerosis (faSScinate): a phase 2, randomised, controlled trial. Lancet. 2016;387(10038):2630-40.

15. Elhai M, Meunier M, Matucci-Cerinic M, et al. EUSTAR (EULAR scleroderma trials and research group). Outcomes of patients with systemic sclerosisassociated polyarthritis and myopathy treated with tocilizumab or abatacept: a EUSTAR observational study. Ann Rheum Dis. 2013;72:1217-20.

16. Saito E, Sato S, Nogi S, et al. A case of rheumatoid arthritis and limited systemic sclerosis overlap successfully treated with tocilizumab for arthritis and concomitant generalized lymphadenopathy and primary biliary cirrhosis. Case Rep Rheumatol. 2014;2014:386328.

17. Kono M, Yasuda S, Kono M, Atsumi T. Tocilizumab reduced production of systemic sclerosis-related autoantibodies and anti-cyclic citrullinated protein antibodies in two patients with overlapping systemic sclerosis and rheumatoid arthritis. Scand J Rheumatol. 2017;8:1-3.

Ready to submit your research? Choose BMC and benefit from:

- fast, convenient online submission

- thorough peer review by experienced researchers in your field

- rapid publication on acceptance

- support for research data, including large and complex data types

- gold Open Access which fosters wider collaboration and increased citations

- maximum visibility for your research: over $100 \mathrm{M}$ website views per year

At $\mathrm{BMC}$, research is always in progress.

Learn more biomedcentral.com/submission 